\section{Mineral chemistry perspective of Nain ophiolite mélange, Central Iran}

\author{
Alireza Eslami ${ }^{1}$, Jyotisankar Ray ${ }^{2, *}$, \\ Madhuparna Paul ${ }^{2}$, Sonia Sarkar ${ }^{2}$, \\ Mousumi Banerjee ${ }^{2}$, Moussa Noghreyan ${ }^{3}$ and \\ Payel Dey ${ }^{2}$ \\ ${ }^{1}$ Department of Economic Geology, Faculty of Sciences, \\ Tarbiat Modares University, Tehran 14115-175, Iran \\ ${ }^{2}$ Department of Geology, University of Calcutta, Kolkata 700019 , \\ India \\ ${ }^{3}$ Department of Geology, Faculty of Sciences, University of Isfahan, \\ Isfahan 81744, Iran
}

The present study documents detailed mineral chemistry perspective of Nain ophiolite mélange (NOM) of Central Iran with an aim of deciphering the mineral systematics and understanding geothermobarometric equilibration. The NOM covers $\sim 600 \mathrm{~km}^{2}$ and is located at the northwest margin of Central Iranian Microcontinental block. NOM is represented by a sheared, tectonized and serpentinized peridotite intruded by coarse-grained pegmatitic gabbroic dykes, layered gabbro, sheeted dolerite dykes (with typical rodingite alteration) and pillow basalts. Plagioclase in pillow basalt is albitic and indicates its spilitic affinity, while pyroxene is typically quad pyroxene (augite to diopside). Amphiboles belong to calcic group and range from actinolite to magnesio hornblende. Ilmenite is the characteristic opaque phase. Clinopyroxene thermometry records a temperature span of 1100$1300^{\circ} \mathrm{C}$, while amphibole thermometry records 979 $1145^{\circ} \mathrm{C}$. Two-feldspar thermometry also records a similar thermometric range. Amphibole barometry shows higher pressure of equilibration for mantle pegmatite in general and a very low equilibration pressure for sheeted dyke. Pyroxene compositions typically indicate a calc-alkaline basaltic (orogenic) parentage. NOM signifies lherzolite ophiolite type in a chromite-free environment and it is analogous to an idealized ophiolite succession, but has been emplaced in the form of discrete tectonic mélange.

Keywords: Amphibole barometry, mineral chemistry, ophiolite mélange, orogenic setting, quad pyroxene.

OPHIOLITES are useful in reconstructing the tectonic history of a region, as they indicate the presence of sutures and closure of ancient oceanic basins. The volcanic and intrusive rock associations preserved in ophiolite complexes offer a tool to evaluate the processes/conditions of basaltic magmatism ${ }^{1}$. Based on their environment and origin or emplacement, ophiolites can be broadly classified into six types: continental margin, mid-ocean ridge, plume, supra-subduction zone, volcanic arc and accretio-

*For correspondence. (e-mail: jsray65@hotmail.com) nary ${ }^{2}$. Ophiolites in Iran are part of the Tethyan ophiolite belt of the Middle East and link the Middle Eastern and Mediterranean Hellenides-Dinarides ophiolites (e.g. Turkish, Trodos, Greek and East European) with further easterly Asian ophiolites (e.g. Pakistani and Tibetan ophiolites) ${ }^{3}$. They have been divided into four groups ${ }^{4-6}$ (Figure $1 \mathrm{a}$ ), namely (i) ophiolites of northern Iran, considered as remnants of the Palaeo-Tethys Ocean ${ }^{7,8}$; (ii) ophiolites of the Zagros Suture Zone, including those of Neyriz and the Kermanshah'; (iii) ophiolites of the Makran region, located to the south of the SanandajSirjan Zone, which include non-fragmented complexes such as Sorkhband and Rudan ${ }^{6,10}$ and (iv) ophiolites enclosed as tectonic blocks in the Late Cretaceous coloured mélange along the main boundaries of the Central Iranian Microcontinental block (CIM; Lut) ${ }^{11}$. The Nain ophiolite mélange (NOM) belongs to the fourth group of Iranian ophiolites ${ }^{10}$. It is part of the Central Iranian ophiolite belt and constitutes the northern parts of the Nain-Baft ophiolite belt ${ }^{12,13}$.

Though fairly detailed knowledge of whole-rock geochemistry of the constituent lithologies of NOM are available in the literature ${ }^{1,14-18}$, efforts to evaluate the mineral chemistry of phases are almost rudimentary. In this view, the present study documents the detailed mineral chemistry perspective of NOM with an aim of deciphering the mineral systematics and understanding geothermobarometric equilibration.

NOM represents highly dismembered ophiolite cropping out north of Nain town to the west of Central Iran. This ophiolite, which covers an area of $\sim 600 \mathrm{~km}^{2}$ is located at the northwest margin of the $\mathrm{CIM}^{1}$. NOM extends from NNW to SSE and is surrounded by sedimentary rocks in the east and volcanic rocks in the west, both being Tertiary in age ${ }^{12}$ (Figure $1 b$ ). Presence of both mantle and crustal sequences has been reported in $\mathrm{NOM}^{19}$. The peridotitic mantle sequence is highly deformed, foliated, sheared and tectonized, often traversed by dykes of plagioclase bearing harzburgite, wehrlite and pyroxenite. The crustal sequence contains pegmatitic gabbro and diabase sheeted dyke complex. In addition, pillow lavas are associated with sheeted basaltic flows and radiolarian chert. NOM is considered to have witnessed several magmatic and metamorphic events related to multiple phases of magma generation during lower Jurassic to upper Cretaceous time ${ }^{20}$.

NOM experienced variable degrees of alteration and fragmentation, owing to shear movements ${ }^{18,20}$. The present study reveals that at the base of Nain ophiolite, a sheared (fault-controlled) tectonized peridotite (Figure $2 a$ ) is well-developed, which is sometimes found to be intruded by coarse-grained pegmatitic gabbroic dykes (Figure $2 b$ ). NOM has also developed constructional (layered) part of the ophiolite, which is manifested in terms of layered gabbro (Figure $2 \mathrm{c}$ ). Characteristic sheeted dolerite dyke is also exposed with typical 

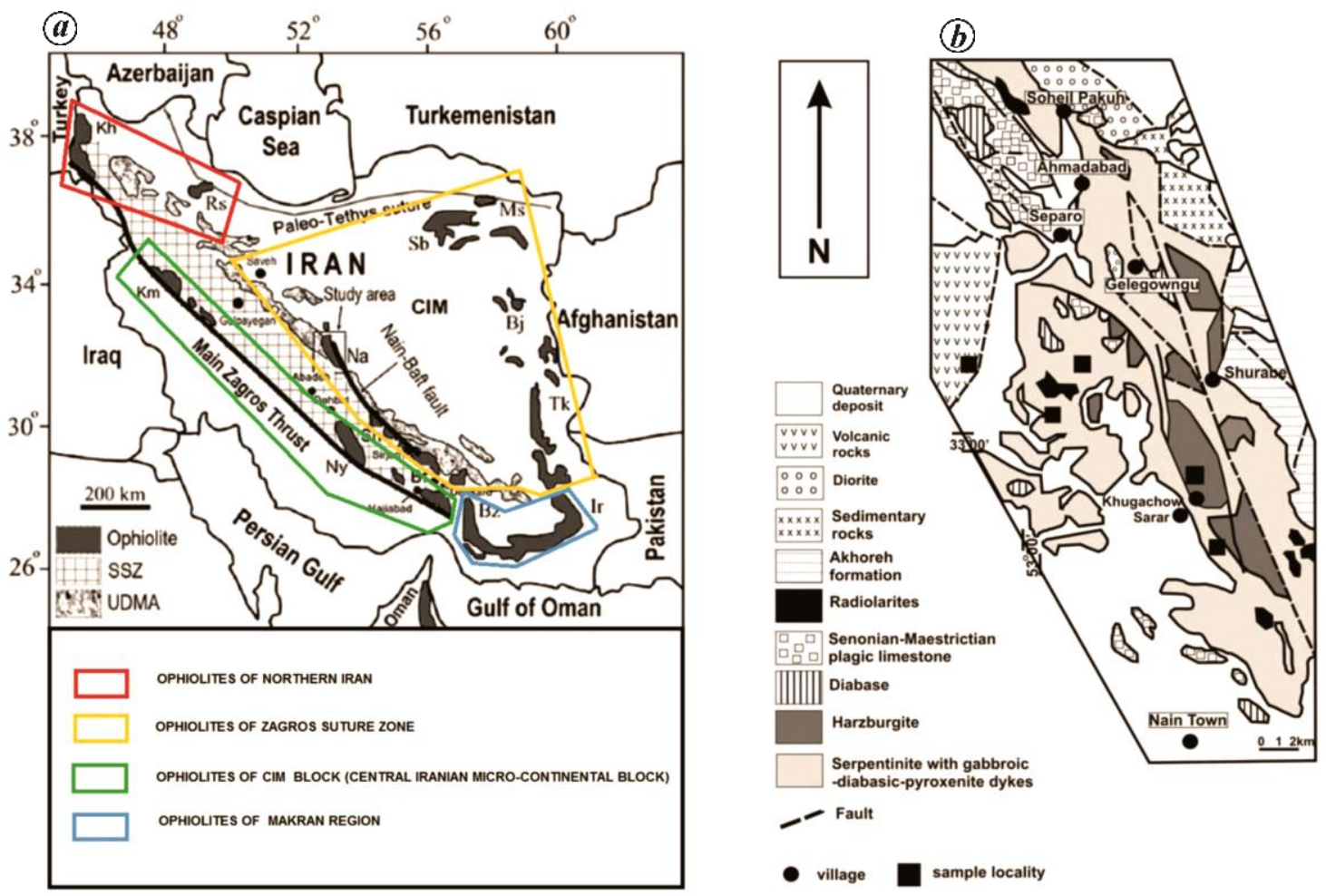

Figure 1. $\boldsymbol{a}$, Distribution of different ophiolites in $\operatorname{Iran}^{35} . \boldsymbol{b}$, Geological map of the Nain ophiolite, $\operatorname{Iran}^{12}$.
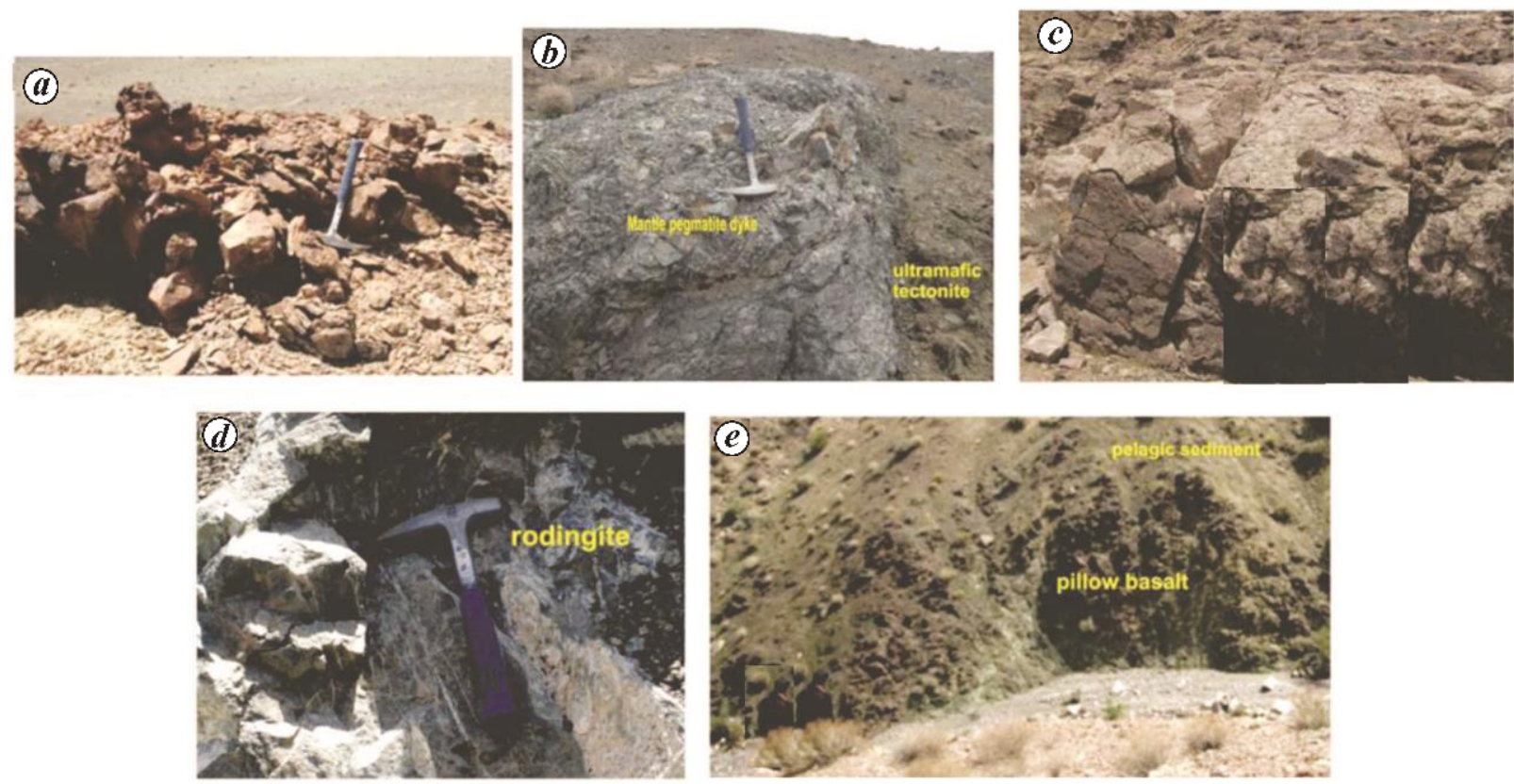

Figure 2. Field photographs of different rock types of Nain ophiolite: $\boldsymbol{a}$, Highly sheared serpentinized lherzolite; $\boldsymbol{b}$, sharp intrusion of coarsegrained mantle pegmatite in peridotite tectonite; $\boldsymbol{c}$, well-developed layering in cumulate gabbro; $\boldsymbol{d}$, rodingite development in sheeted dyke; $\boldsymbol{e}$, disposition of pillow lava with pelagic sediments on top.

rodingite alteration (Figure $2 d$ ). Pillow basalts are found in several localities of the Nain ophiolite, and they display small to large, well-preserved or brecciated pillow structure with a cover of pelagic sediments on top (Figure $2 e)$.
In the present study, a number of petrographic types have been observed in NOM, namely, serpentinized lherzolite, pegmatitic dyke intrusive into the mantle (mantle pegmatite), cumulus gabbro, sheeted dyke and pillow basalt. Serpentinized lherzolites are highly altered, highly 

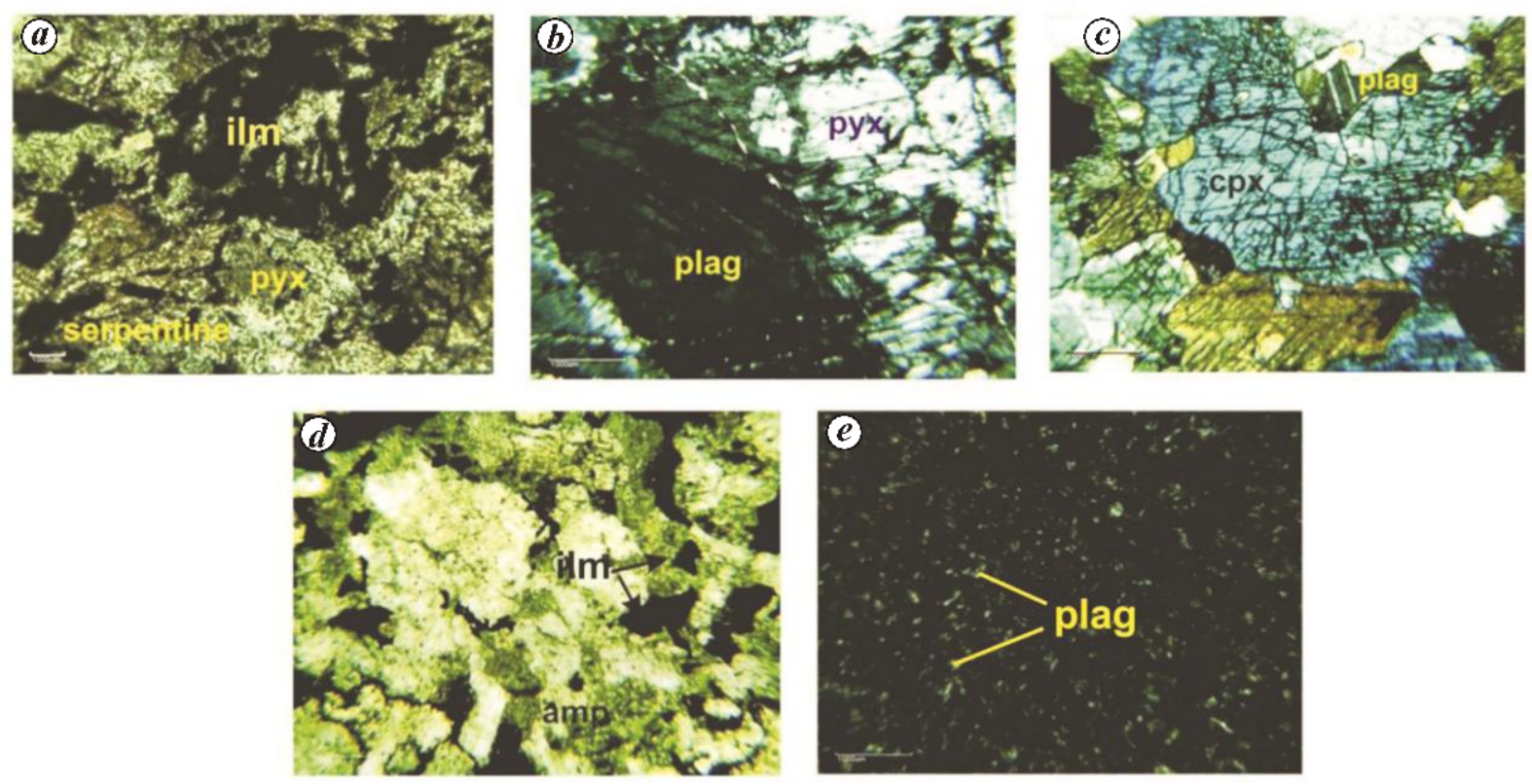

Figure 3. Photomicrographs of different rock types of Nain ophiolite: $\boldsymbol{a}$, Presence of pyroxene and opaque grains in a highly serpentinized, sheared matrix; $\boldsymbol{b}$, coarse-grained plagioclase (extinct position) and clinopyroxene in mantle pegmatite; $\boldsymbol{c}$, well-developed cumulus texture defined by plagioclase and clinopyroxene grains in layered gabbro; $\boldsymbol{d}$, presence of opaque and amphibole grains in a sheeted dyke sample; $\boldsymbol{e}$, numerous fine laths of plagioclase and clinopyroxene, indicating extremely chilling effect in pillow basalt.

(a)

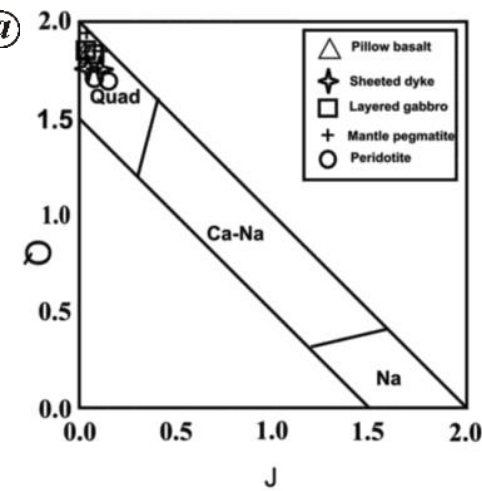

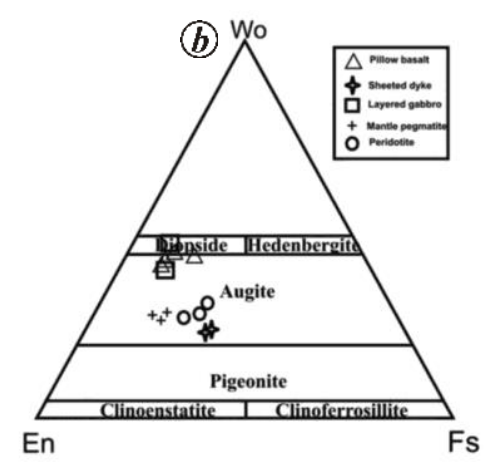

Fs

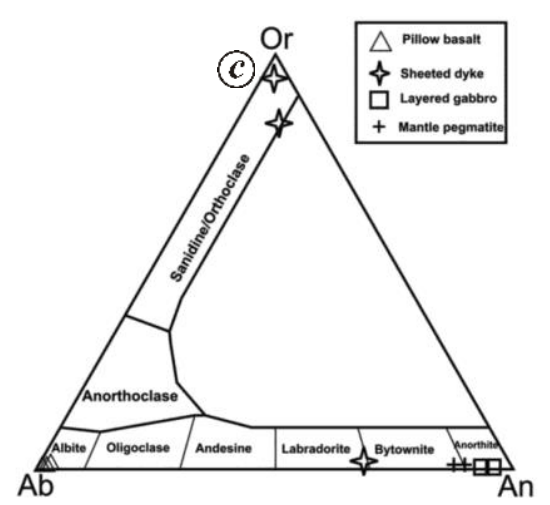

Figure 4. $\boldsymbol{a}$, Pyroxene compositions of Nain ophiolite in $\mathrm{Q}(\mathrm{Ca}+\mathrm{Mg}+\mathrm{Fe})-\mathrm{J}(2 \mathrm{Na})$ diagram $^{21}$. $\boldsymbol{b}$, Pyroxene compositions of Nain ophiolite in Wo-En-Fs diagram ${ }^{22} . c$, Composition of feldspar from Nain ophiolite in $\mathrm{Or}-\mathrm{Ab}-\mathrm{An}$ diagram.

serpentinized and ferruginized with minor presence of relict olivine and clinopyroxene. Plagioclase and ilmenite occur as accessory minerals. The rock has overall porphyroclastic and locally mylonitic texture (Figure $3 a$ ). The gabbroic pegmatite contains plagioclase and clinopyroxene together with accessory ilmenite; amphibole, epidote and chlorite are present as secondary minerals. Brecciated and intercumulus textures are prominent (Figure $3 b$ ). Layered gabbro is coarse-grained and consists of plagioclase and clinopyroxene developing a typical hypidiomorphic texture. Presence of exsolved lamellae of orthopyroxene within clinopyroxene is a characteristic feature of this rock. It shows cumulus plagioclase which is enclosed within intercumulus clinopyroxene giving rise to ophitic texture (Figure $3 \mathrm{c}$ ). The gabbro mainly defines the sheeted dyke and it is coarse-grained with characteristic presence of orthopyroxene, clinopyroxene, saussuritized plagioclase with subordinate amphibole and ilmenite. Ilmenite occurs in moderate amount and characteristically occurs along the margin of the other mafic minerals (Figure $3 d$ ). This rock shows overall hypidiomorphic texture. Pillow basalt are characteristically glassy with occasional development of tiny plagioclase and clinopyroxene. A pilotaxitic texture is common in pillow basalt (Figure $3 e$ ).

Minerals were analysed at the Geological Survey of India, Kolkata, using a microprobe (Cameca SX-100). The accelerating voltage and beam current were $15 \mathrm{kV}$ and $12 \mathrm{nA}$ respectively, while beam diameter was $1 \mu \mathrm{m}$. Both natural and synthetic standards were used for data calibration. Representative chemical compositions of 

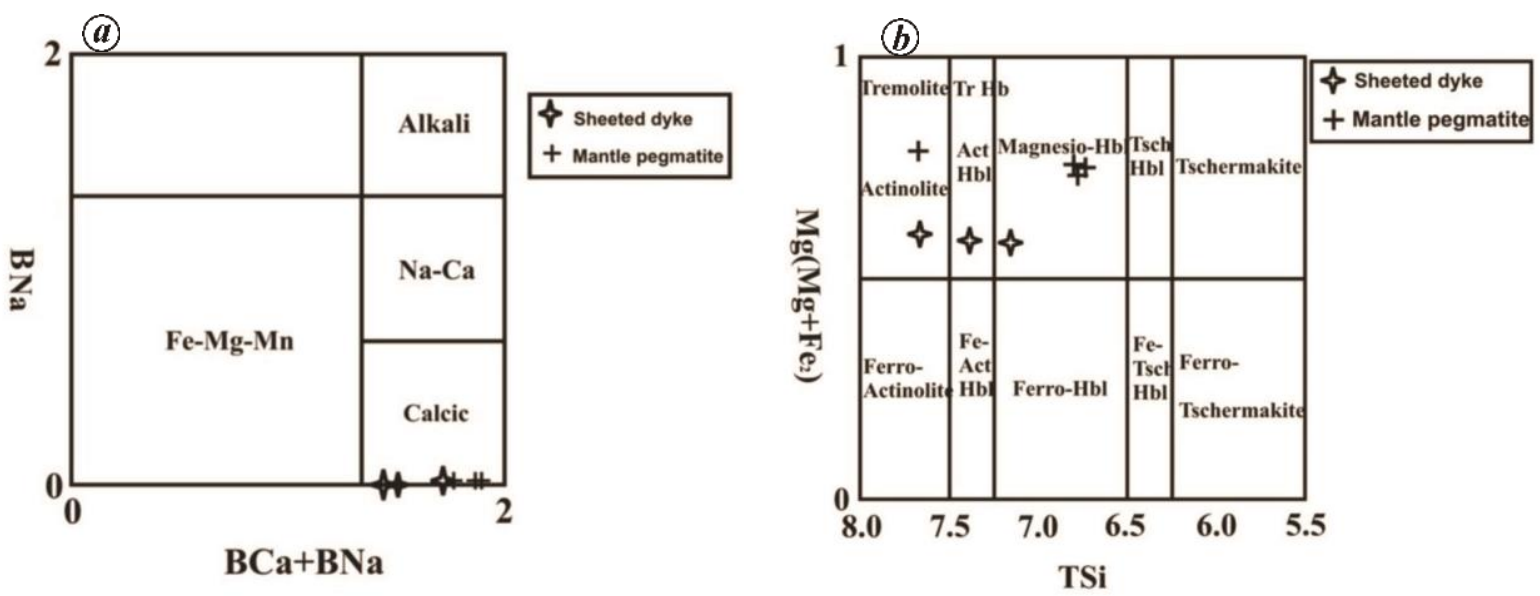

Figure 5. $\boldsymbol{a}$, Plot of amphibole compositions from Nain ophiolite in $\mathrm{B}_{\mathrm{Na}}$ versus $\mathrm{B}_{\mathrm{Ca}}+\mathrm{B}_{\mathrm{Na}}$ diagram ${ }^{23}$. $\boldsymbol{b}$, Composition of amphiboles from Nain ophiolite in $\mathrm{Mg} /\left(\mathrm{Mg}+\mathrm{Fe}^{2+}\right)$ versus $\mathrm{T}_{\mathrm{Si}}$ diagram ${ }^{23}$.
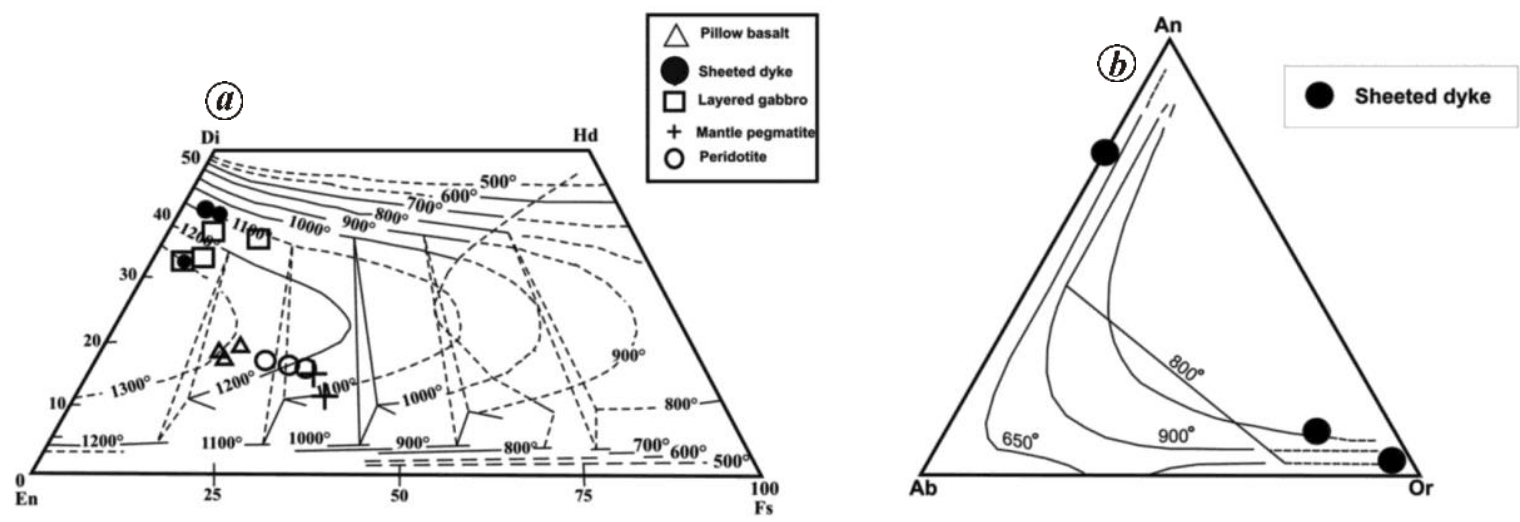

Figure 6. $\boldsymbol{a}$, Projection of recalculated pyroxene composition in diopside (Di)-hedenbergite (Hd)-enstatite (En)-ferrosilite $(\mathrm{Fs})$ diagram $^{25}$ for thermometric calculations $\left({ }^{\circ} \mathrm{C}\right)$. $\boldsymbol{b}$, Projection of $\mathrm{Or}-\mathrm{Ab}-\mathrm{An}$ composition in ternary feldspar diagram for two-feldspar thermometric calculations $\left({ }^{\circ} \mathrm{C}\right)^{27}$.

clinopyroxene, feldspar, amphibole and opaque mineral (ilmenite) are provided in Supplementary Tables 1-4 respectively. In terms of $\mathrm{Q}$ and $\mathrm{J}$, where $\mathrm{Q}=\mathrm{Ca}+\mathrm{Mg}+\mathrm{Fe}$ and $\mathbf{J}=2 \mathrm{Na}$ (ref. 21) (expressed in terms of a.p.f.u), the pyroxenes compositions (Supplementary Table 1) are designated as quad pyroxenes 22 (Figure $4 a$ ). Pyroxenes of the pillow basalt are either diopside or they are transitional between diopside and augite. Pyroxenes of peridotite, sheeted dyke, mantle pegmatite and layered gabbro have augitic composition, whereas some pyroxenes from layered gabbros also have diopsidic composition (Figure $4 b$ ). The plagioclase composition (Supplementary Table 2) has been plotted in an Or-Ab-An triangular diagram (Figure $4 c$ ). It shows plagioclase of pillow basalt to be albitic in composition, which suggests its spilitic affinity, whereas plagioclase from layered gabbro is comparatively much calcic. Plagioclase belonging to mantle pegmatite is highly anorthitic $\left(\mathrm{An}_{90}\right)$. Orthoclase is present only in sheeted dyke samples, where it occurs as accessory. Amphibole data are available from sheeted dyke and pegmatitic samples (Supplementary Table 3). Amphiboles are all 'calcic' in the classification scheme $\mathrm{e}^{23,24}$ (Figure $5 a$ ). Further, on the basis of $\mathrm{Mg} / \mathrm{Mg}+\mathrm{Fe}^{2+}$ versus $\mathrm{T}_{\mathrm{Si}}$ (Figure $5 \mathrm{~b}$ ), the amphiboles of both dyke and pegmatitic samples range from actinolite to magnesio-hornblende. EPMA data of ilmenite are provided in Supplementary Table 4. Ilmenites are characterized by trace quantities of $\mathrm{Al}_{2} \mathrm{O}_{3}$ and $\mathrm{Cr}_{2} \mathrm{O}_{3}$ with appreciably high $\mathrm{TiO}_{2}$ and $\mathrm{FeO}$. The $\mathrm{TiO}_{2}$ content of ilmenite is $47.86-52.17 \mathrm{wt} \%$ and that of $\mathrm{FeO}$ is 43.48-48.68 wt\%. Chromespinels reported from NOM by other researchers were not found in the present study.

From the available mineral chemistry data, pyroxene thermometry, amphibole thermometry and two-feldspar thermometry were utilized. Pyroxene thermometry yielded and estimated temperature which varied between $1100^{\circ} \mathrm{C}$ and $1300^{\circ} \mathrm{C}$ (Figure $6 a$ ) for the different rock units of $\mathrm{NOM}^{25}$. Amphibole thermometric data (mantle pegmatite dyke and sheeted dyke) gave a temperature range from $979^{\circ} \mathrm{C}$ to $1145^{\circ} \mathrm{C}$ (Supplementary Table 5) $)^{26}$. Two-feldspar thermometry (based on coexisting plagioclase and potassium feldspar) presented temperature ranging from $650^{\circ} \mathrm{C}$ to $800^{\circ} \mathrm{C}$ for sheeted dyke (Figure $\left.6 \mathrm{~b}\right)^{27}$. 

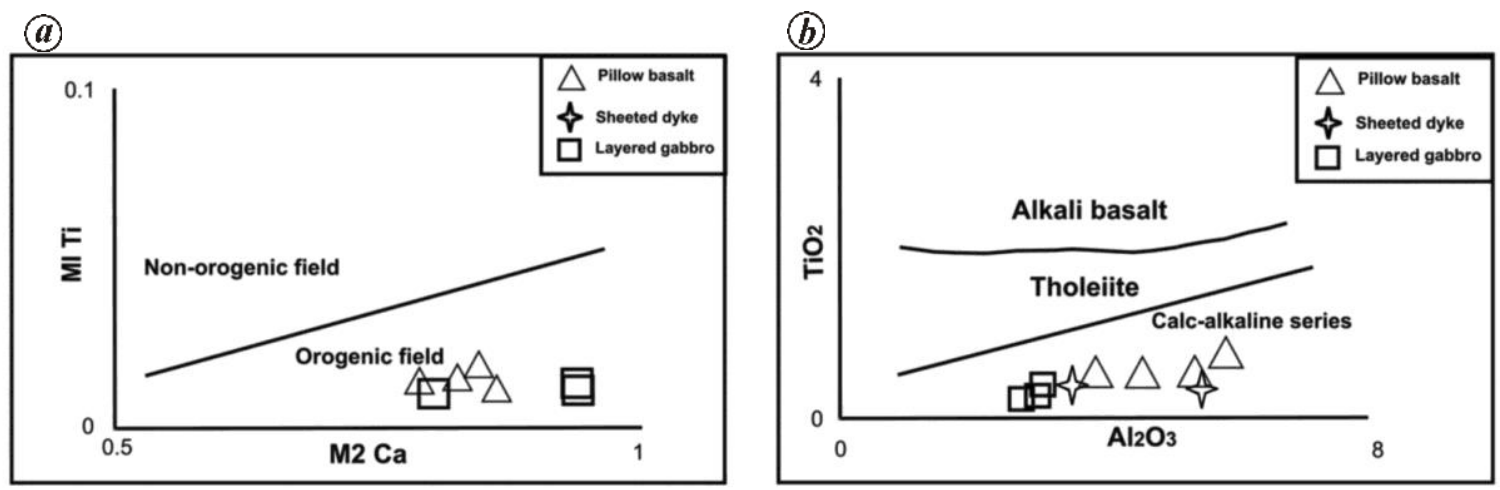

Figure 7. Plots of analysed pyroxene composition from the studied Nain Ophiolite Complex in: $\boldsymbol{a}$, $\mathrm{Ti}^{\mathrm{i}}$ versus $\mathrm{Ca}$ diagram ${ }^{29} ; \boldsymbol{b}$, $\mathrm{TiO}_{2}$ versus $\mathrm{Al}_{2} \mathrm{O}_{3}$ diagram $^{36}$. (For both $\boldsymbol{a}$ and $\boldsymbol{b}$ analyses corresponding to serpentinized lherzolite and mantle pegmatite have been excluded.)

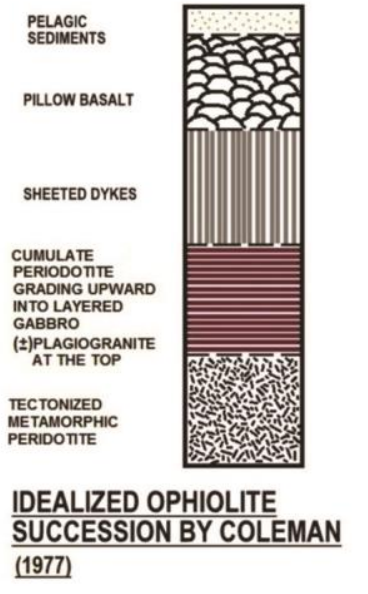

Figure 8. Comparison between idealized ophiolite ${ }^{34}$ and Nain ophiolite (present study).

Amphibole barometry revealed that the deduced pressure was low (ranging from 0.07 to $3.94 \mathrm{kB}$ ) for sheeted dyke, whereas for mantle pegmatite, the pressure ranged from 3.78 to $3.94 \mathrm{kB}$ (Supplementary Table 5$)^{28}$. The deduced low pressure value for sheeted dyke is related to shallowlevel intrusion, while the deduced pressure for mantle pegmatite indicates rapid exhumation and equilibration of the mantle pegmatite along the favourable structural control.

The present study documents detailed mineralogical characteristics of different members of NOM. Further an attempt has been made to systematize the mineral compositions and to understand the nature of geothermobarometric evolution of NOM.

Comparison of deduced clinopyroxene thermometry and amphibole thermometry gave an overlapping range close to $1100^{\circ} \mathrm{C}$ as overall equilibration temperature; however, influence of even lesser temperature may be hinted because of the presence of hydrous phase-like amphibole. Two-feldspar thermometry also gives a similar range of temperature. Amphibole barometry (for dif- ferent litho-members) is consistent with mantle crustal section of an ophiolite succession.

Pyroxene chemistry was used to assess tectonic setting. Pyroxene compositions in terms of $\mathrm{M}_{1} \mathrm{Ti}$ versus $\mathrm{M}_{2} \mathrm{Ca}$ diagram $^{29}$ suggest orogenic field (Figure $7 a$ ). Moreover, projection of the analysed pyroxene compositions on $\mathrm{TiO}_{2}$ versus $\mathrm{Al}_{2} \mathrm{O}_{3}$ diagram distinctly reflected a calcalkaline parentage (Figure $7 \mathrm{~b}$ ) of NOM. On the basis of the present study, we contemplate a supra-subduction zone (SSZ) related orogenic setting environment for Nain ophiolite. However, earlier studies from other parts of the Nain ophiolite revealed the presence of chromite-spinels as the opaque phase $\mathrm{e}^{14,16,18,19}$. If this be the situation, much depends upon the mantle peridotite section. It has been observed by workers that chromite is generally absent in those ophiolites where the peridotite section is lherzolite belonging to the lherzolitic ophiolite type (LOT) $)^{30,31}$. Our petrographic observation indicates presence of lherzolite mantle in NOM, which again corroborates presence of ilmenite in a chromite-free environment controlled by melting history ${ }^{32,33}$.

The question that however persists is whether NOM represents a dismembered ophiolite or not. Figure 8 shows a comparison between idealized ophiolite succession and that of NOM. This indicates identical presence of lithounits in NOM with respect to idealized succession. However, NOM is marked by (i) dyke intrusion within the mantle lherzolite, and (ii) absence of ultramafic cumulate and pelagic sediments. Therefore, by and large, NOM is analogous to idealized ophiolite but it appears that different portions of NOM were emplaced as discrete tectonic mélanges ${ }^{34}$.

The mineral chemistry data of NOM help to characterize constituent mineral phases of its different litho-members. Application of pyroxene, amphibole and two-feldspar thermometry gives $1100^{\circ} \mathrm{C}$ (or less) as overall equilibration temperature of NOM. Amphibole barometry gives a pressure of 0.07 to $3.94 \mathrm{kB}$ (corresponding to different litho-members), consistent with mantle crustal section. Chemistry of pyroxene typically indicates orogenic supra 


\section{RESEARCH COMMUNICATIONS}

subduction setting. NOM signifies LOT in a chromitefree environment controlled by mantle melting history and tectonic milieu. NOM has been suggested to be analogous to idealized ophiolite succession, but has been emplaced in form of discrete tectonic mélanges ${ }^{34}$.

1. Ghazi, J. M., Rahgoshay, M., Shafaii Moghadam, H. and Moazzen, M., Geochemistry of Gabbroic pockets of a mantle sequence in the Nain ophiolite (Central Iran): constraints on petrogenesis and tectonic setting of the ophiolite. J. Mineral. Geochem., 2010, 187, 49-62.

2. Dilek, Y. and Furnes, H., Ophiolite genesis and global tectonics: geochemical and tectonic fingerprinting of ancient oceanic lithosphere. Geol. Soc. Am. Bull., 2011, 123, 387-411.

3. Shojaat, B., Hassanipak, A. A., Mobasher, K. and Ghazi, A. M., Petrology, geochemistry and tectonics of the Sabzevar ophiolite, North Central Iran. J. Asian Earth Sci., 2003, 21, 1053-1067.

4. Takin, M., Iranian geology and continental drift in the Middle East. Nature, 1972, 23, 147-150.

5. Stöcklin, J., Possible ancient continental margin in Iran. In The Geology of Continental Margins (eds Burke, C. A. and Drake, C. L.), Springer, Berlin, 1974, pp. 873-887.

6. McCall, G. J. H., The geotectonic history of the Makran and adjacent areas of southern Iran. J. Asian Earth Sci., 1997, 15, 517531.

7. Ruttner, A. W., Southern borderland of Triassic Laurasia in northeast Iran. Int. J. Earth Sci., 1993, 82, 110-120.

8. Moazzen, M., Omrani, H., Oberhänsli, R., Moayyed, M., Tsujimori, T. and Bousequet, R., Shanderman eclogites from northern Iran, $\mathrm{P}-\mathrm{T}$ path and paleotethys geodynamics from subduction to exhumation. In MSA Meeting, Tectonic Crossroads: Evolving Orogens of Eurasia-Africa-Arabia Conference, Ankara Turkey, October 2010

9. Lanphere, M. A. and Pamić, J., ${ }^{40} \mathrm{Ar} /{ }^{39} \mathrm{Ar}$ Age and tectonic setting of ophiolites from Neyriz area, south-east Zagros ranges, Iran. Tectonophysics, 1983, 96, 245-256.

10. Ghazi, A. M., Hassanipak, A. A., Mahoney, J. J. and Duncan, R A., Geochemical characteristics, ${ }^{40} \mathrm{Ar}-{ }^{39} \mathrm{Ar}$ ages and original tectonic setting of the Band-e-Zeyarat/Dar Anar ophiolite, Makran Accretionary Prism, south-east Iran. Tectonophysics, 2004, 393, 175-196.

11. Berberian, M. and King, G. C. P., Towards paleogeography and tectonic evolution of Iran. Can. J. Earth Sci., 1981, 18, 210-265.

12. Davoudzadeh, M., Geology and petrology of the area north of Nain, Central Iran. Geological Survey of Iran, Report No. 1, 1972.

13. Arvin, M. and Robinson, P. T., The petrogenesis and tectonic setting of lavas from the Baft ophiolitic mélange, south-west of Kerman, Iran. Can. J. Earth Sci., 1994, 31, 824-834.

14. Ghazi, J. M., Moazzen, M., Rahgoshay, M. and Shafaii Moghadam, H., The geodynamic setting of the Nain ophiolites, Central Iran: evidence from chromian spinels in the chromitites and associated rocks. Ofioliti, 2011, 36, 59-76.

15. Rahmani, F., Nogreyan, M. and Khalili, M., Geochemistry of sheeted dikes in the Nain ophiolite (Central Iran). Ofioliti, 2007, 32, 119-129.

16. Shafaii Moghadam, H., Rahgoshay, M. and Banitaba, A., Geochemistry and petrogenesis of basaltic flows in the Nain-Dehshir ophiolites, Iran. Iran. J. Crystallogr. Mineral., 2009, 16, 602-611.

17. Shafaii Moghadam, H., Whitechurch, H., Rahgoshay, M. and Monsef, I., Significance of Nain-Baft ophiolitic belt (Iran): shortlived, transitional Cretaceous back-arc oceanic basins over the Tethyan Subduction Zone. C. R. Geosci., 2009, 341, 1016-1028.

18. Ghazi, J. M., Moazzen, M., Rahgoshay, M. and Shafaii Moghadam, H., Mineral-chemical composition and geodynamic significance of peridotites from Nain ophiolite, Central Iran. $J$. Geodyn., 2010, 49, 261-270.
19. Foudazi, M. and Mahabadi, S. A., Petrography and mineralogy study of the ultramafic rocks in Separou peridotites, Nain ophiolite, Central Iran. Geophys. Res. Abstr., 2010, 12, EGU2010-56023.

20. Shirdashtzadeh, N., Torabi, G. and Arai, S., Metamorphism and metasomatism in the Jurassic Nain ophiolitic mélange, Central Iran. Neues. Jahrb. Geol. Palaeontol., 2010, 255, 255-275.

21. Morimoto, N. et al., Nomenclature of pyroxenes. Am. Mineral., 1988, 73, 1123-1133.

22. Morimoto, N., Nomenclature of pyroxenes. Can. Mineral., 1989, 27, 143-156.

23. Leake, B. E., Nomenclature of amphiboles. Mineral. Mag., 1978, 42, 533-563.

24. Leake, B. E. et al., Nomenclature of amphiboles: Report of the Subcommittee on Amphiboles of the International Mineralogical Association, Commission on New Minerals and Mineral Names. Can. Mineral., 1997, 35, 219-246.

25. Lindsley, D. H., Pyroxene thermometry. Am. Mineral., 1983, 68 477-493.

26. Nabelek, C. R. and Lindsley, T. H., Tetrahedral Al in amphibole: a potential thermometer for some mafic rocks. Annual Meeting, Geological Society of America, Orlando, Fla, USA, 1985, p. 673.

27. Brown, W. L. and Pearsons, I., Calorimetric and phase diagram approaches to two-feldspar geothermometry: a critique. Am. Mineral., 1985, 70, 356-361.

28. Hammarstrom, J. M. and Zen, E., Aluminum in hornblende: an empirical igneous geobarometer. Am. Mineral., 1986, 71, 1297 1313.

29. Leterrier, J., Maury, R. C., Thonon, P., Girard, D. and Marchal, M., Clinopyroxene composition as a method of identification of the magmatic affinities of paleo-volcanic series. Earth Planet. Sci. Lett., 1982, 59, 139-154.

30. Nicolas, A., Structure and petrology of peridotites. Rev. Geophys., 1986, 24, 875-895.

31. Nicolas, A. and Azri, H. A., Chromite-rich and chromite-poor ophiolites: the Oman case. In Ophiolite Genesis and Evolution of the Oceanic Lithosphere (eds Tj. Peters, Nicolas, A. and Coleman, R. G.), Kluwer Academic, Dordrecht, The Netherlands, 1991, pp. 261-274.

32. Roberts, S., Ophiolitic chromitite formation: a marginal basin phenomenon? Econ. Geol., 1988, 83, 1034-1036.

33. Shastry, A., Srivastava, R. K., Chandra, R. and Jenner, G. A., Fe-Ti-enriched mafic rocks from south Andaman ophiolite suite: implication of late stage liquid immiscibility. Curr. Sci., 2001, 80, 453-454.

34. Coleman, R. G., Ophiolites: Ancient Oceanic Lithosphere? Springer-Verlag, Berlin, 1977, p. 229.

35. Emami, M. H., Sadegi, M. M. and Omrani, S. J., Magmatic map of Iran. Scale $1: 1,00,000$. Geological Survey of Iran, 1993.

36. Le Bas, M. J., The role of aluminum in igneous clinopyroxenes with relation to their parentage. Am. J. Sci., 1962, 260, 267-288.

ACKNOWLEDGEMENTS. The present study is the outcome of a collaborative project between University of Calcutta, India and University of Isfahan, Iran. We thank the authorities of both the universities for granting permission to carry out this project. We also thank $\mathrm{Dr}$ Shyamal Sengupta (Geological Survey of India, Kolkata) for assistance during EPM analyses, and the anonymous reviewers for their useful comments that helped improve the manuscript.

Received 23 January 2018; revised accepted 13 March 2019

doi: $10.18520 / \mathrm{cs} / \mathrm{v} 116 / 110 / 1742-1747$ 